\title{
Sutry jako źródło weryfikacji bezpośredniego wglądu w tradycji buddyzmu chan
}

\author{
Kamil Nowak \\ Instytut Religioznawstwa \\ Uniwersytet Jagielloński
}

\section{Abstract \\ The Sutras as a Source of Verification of a Direct Insight within the Tradition of Chan Buddhism}

The article discusses the connection between Chan Buddhism and the study of the Sutras and Sastras. The first part shows the prevalent view according to which Chan negates the value of texts, focusing only on the direct experience. The author then shows the historical dependence of this view and its lack of compatibility with many Chan Buddhist schools. In the later part, the author discusses the Wenzi Chan current and, based on its postulates, carries out an analysis of the texts belonging to the early Chan tradition. This aims to prove that, contrary to the view presented at the beginning of the article, one can demonstrate the existence of a highly influential movement in which the Sutras are valued equally to the direct insight.

Key words: Chan, sutras, Zongmi, Yanshou, Wenzi Chan

Słowa kluczowe: chan, sutry, Zongmi, Yanshou, wenzi chan

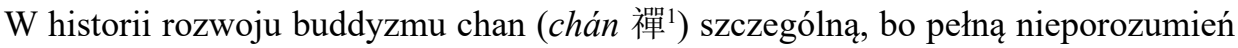
rolę odegrał stosunek mistrzów chan (chánshī 禪師) do studiowania sutr i śastr. Celem niniejszego artykułu jest ukazanie złożoności owej relacji i wykazanie, że wbrew wciąż powszechnemu przekonaniu o tym, iż chan w historii swojego rozwoju funkcjonował niezależnie od sutr, lub nawet w opozycji do nich, istniał w tradycji buddyzmu chan nurt, w którym sutry pełniły równie istotną rolę, co bezpośrednie doświadczenie.

${ }^{1}$ Chińskie terminy źródłowe podaję kolejno w transkrypcji pinyin i w znakach tradycyjnych; terminy koreańskie - w transkrypcji poprawionej i w hanja; terminy palijskie i sanskryckie podaję $\mathrm{w}$ transkrypcji IAST. W celu ułatwienia dyskursu stosuję także spolszczenia. 
Zgodnie $\mathrm{z}$ rozpowszechnionym poglądem, istotą buddyzmu chan nie jest studiowanie tekstów buddyjskich, lecz bezpośredni wgląd w to, co stanowi ich treść. Poglądy tego rodzaju często wyrażane są za pomocą metafory palca wskazującego na księżyc, w której to metaforze księżyc symbolizuje treść nauk buddyjskich, a palec słownie wyrażoną doktrynę, którą wypełnia owa treść. Skoro można zobaczyć księżyc bezpośrednio, palec nie jest potrzebny. Doktryna wyrażona w języku jest więc zbędna, jeśli można osiągnąć bezpośredni wgląd (przebudzenie) w jej istotę (i tak niewerbalną). Zgodnie z owym przekonaniem, tradycja buddyzmu chan funkcjonuje, opierając się na sukcesji patriarchów (ž̌ 祖), z których każdy uzyskał potwierdzenie swojego przebudzenia od poprzedzającego go patriarchy. Owa sukcesja w założeniu sięga wstecz do czasów historycznego Buddy. Tradycja chan miałaby przekazywać nauki, które Budda powierzył swojemu uczniowi, Mahakassapie, a ten z kolei następnym patriarchom indyjskim, aż do Bodhidharmy i dalej do czasów współczesnych. Model ten wyraża tradycyjna formuła „specjalnego przekazu poza nauczaniem, który nie opiera się na literaturze" (jiàowài biéchuán bù lì wénzì 教外別傳不立文字 $)^{2}$. Chan tak ujęty przeciwstawiany jest innym szkołom buddyzmu wschodnioazjatyckiego, które opierają się na wybranych sutrach ${ }^{3}$. Jak stwierdził Daisetz Teitaro Suzuki w swoim Wprowadzeniu do buddyzmu zen:

[...] zen z całą mocą i uporem domaga się wewnętrznego duchowego przeżycia. Nie przywiązuje on istotnej wagi ani do świętych sutr, ani do ich egzegezy przez mędrców i uczonych. Autorytetom i obiektywnym odkryciom przeciwstawia zdecydowanie osobiste przeżycie... ${ }^{4}$.

Jak wykazali współcześni badacze buddyzmu chan, tacy jak Albert Welter ${ }^{5}$ czy Jeffrey Broughton ${ }^{6}$, pogląd, zgodnie z którym chan neguje wartość studiowania sutr, wywodzi się z retoryki typowej głównie dla szkoły linji (línji 臨濟) i szkoły yunmen (yúnmén 雲門), z których ta druga nota bene została wchłonięta przez szkołę linji w okresie dynastii Song (960-1279). Pogląd ów stał się dominujący, bowiem szkoła linji zdominowała w okresie dynastii Song nie tylko szkołę yunmen, ale niemal

${ }^{2}$ Termin wénzi文字, który tutaj oddaję jako ,literatura”, ma szerokie pole znaczeniowe, obejmujące ogólnie treści wyrażone w piśmie. W kontekście buddyzmu oznacza nauki buddyjskie wyrażone słownie i zapisane w postaci sutr i śastr.

${ }^{3}$ Przykładowo, szkoła tiantai (tiāntái 天台) opiera się głównie na Sutrze lotosu, a szkoła niepan (nièpán 涅槃) - na Sutrze nirwany... O znaczeniu, jakie dla danej szkoły miał wybrany tekst, świadczy fakt nazywania szkół od tytułów sutr czy śastr (niepan, huayan, shelun, dilun...). Nie oznacza to jednak, że dana szkoła negowała znaczenie innych sutr i nie poświęcała im uwagi, a jedynie - iż wybrana sutra była uznawana za najważniejszą, bo przekazującą najbardziej zaawansowane nauki. Nazwy szkół chan z kolei wywodzą się najczęściej od imion założycieli (Niutou, Heze, Linji, Yunmen, Fayan...).

${ }^{4}$ D.T. Suzuki, Wprowadzenie do buddyzmu zen, Kraków 2009, s. 40; podobne poglądy głosili również inni japońscy badacze i adepci buddyzmu zen (na przykład S. Hisamatsu, Critical Sermons of the Zen Tradition, thum. Ch. Ives, G. Tokiwa, New York 2002, s. 24-26, 61, 92, 100; M. Abe, Zen and Comparative Studies, London 1997, s. 19-20; K. Nishitani, The Philosophy of Nishitani Keiji 1900-1990: Lectures on Religion and Modernity, thum. J. Augustine, S. Yamamoto, New York 2012, s. 42, 47-48). Tego rodzaju wizja buddyzmu chan/zen popularna jest także wśród zachodnich buddystów.

${ }^{5}$ A. Welter, The Linji Lu and the Creation of Chan Orthodoxy, New York 2008.

${ }^{6}$ J. Broughton, Zongmi on Chan, New York 2009. 
cały buddyzm chan ${ }^{7}$. Ponadto wczesne badania nad buddyzmem chan, jakie przeprowadzono w ubiegłym wieku, zostały zapoczątkowane przez japońskich badaczy związanych z tradycją rinzai zen (japoński odpowiednik linji chan), takich jak przede wszystkim cytowany powyżej Suzuki ${ }^{8}$. Rozpatrywany pogląd zatem związany jest głównie z jedną ze szkół chan, a jego rozpowszechnienie nastąpiło stosunkowo późno w historii rozwoju tradycji, ponieważ okres dynastii Song pokrywa się z ostatnim etapem kształtowania się jej specyfiki.

Gdyby spróbować odnieść pogląd o nieprzydatności studiowania sutr do pozostałych szkół buddyzmu chan, z pewnością nie harmonizowałby on ze stanowiskiem typowym dla szkół, takich jak dongshan (dōngshān 東山), heze (hézé 菏泽), guiyang (guīyăng 潙仰) czy fayan (făyăn 法眼). W szczególności ostatnia z wymienionych szkół, czyli fayan, wykazuje przeciwną do linji postawę wobec sutr i śastr.

Nurtem, który koresponduje z poglądami szkoły fayan, jest wenzi chan (wénzì chán 文字禪), czyli chan oparty na literaturze'. Pojęcie to nawiązuje do bù lì wénzì, czyli „nieopierania się na literaturze” i, afirmując wénzì (literaturę), wyraża jego przeciwieństwo. Jest to zatem chan, który nie odrzuca sutr i śastr, lecz traktuje studia nad nimi jako istotny czynnik prowadzący do przebudzenia. Sutry i śastry pełnią funkcję środków służących weryfikacji doświadczenia wglądu u danego adepta chanu. Punktem odniesienia nie jest jedynie autorytet mistrza, ale również autorytet sutr (śastry rozumiane są przede wszystkim jako teksty przybliżające znaczenie sutr, więc pośrednio odwołują się one, tak jak sutry, do autorytetu historycznego Buddy). Zgodnie z przekonaniem, iż zarówno sutry, jak i sukcesja patriarchów mają swoje źródło w osobie Buddy Śakjamuniego, obydwa punkty odniesienia są uznawane w ramach nurtu wenzi chan za właściwe i względem siebie komplementarne. Przedstawiciele nurtu mówią w tym kontekście, że umysł Buddy (reprezentowany przez tradycję chan) i jego „usta” (sutry), mając wspólne źródło, nie mogą stać w sprzeczności ${ }^{10}$.

Za najbardziej wpływowego przedstawiciela nurtu wenzi chan uznawany jest, żyjący w pierwszej połowie IX wieku, przedstawiciel szkoły heze i piąty patriarcha szkoły huayan (huáyán 華嚴) ${ }^{11}$, Guifeng Zongmi (Guīfêng Zōngmì 圭峰宗密, 780-841). Zongmi zapisał się w historii buddyzmu chan jako zwolennik łączenia medytacji ze studiowaniem sutr i jako autor pierwszej historycznej analizy wczesnych szkół chan. Dzieło to, zatytułowane Przedmowa do zbioru tekstów na temat źródel chanu (Chányuán zhūquánjí dūxù 禪源諸詮集都序), stanowiło wprowadzenie do

${ }^{7}$ Zob. A. Welter, op.cit., s. 39-41.

${ }^{8}$ Zob. B. Faure, Chan Insights and Oversights, Princeton 1993, s. 52-60; A. Welter, op.cit., s. $21-$ 24; J. Broughton, op.cit., s. 2-3.

${ }^{9}$ Ibidem, s. 42.

${ }^{10}$ A. Welter, Yongming Yanshou 's Conception of Chan, New York 2011, s. 79-80.

${ }^{11}$ Historia tradycji chan i huayan przeplatała się w różnych okresach i w różnych aspektach, dostarczając wzajemnej inspiracji; na temat relacji między huayan a chan w odniesieniu do klasyfikacji nauk i koncepcji nagłego oświecenia zob. P. Gregory, The Place of the Sudden Teaching within the Hua-yen Tradition: An Investigation of the Process of Doctrinal Change, „Journal of the International Association of Buddhist Studies" 1983, nr 6/1; na temat związku huayan ze szkołą dongshan zob. J. Benická, Chan Buddhism and Huayan: Yongjue Yuanxian (1578-1657) on the „Five Positions” (wu wei) Theory of Dongshan Liangjie, „Письменные памятники Востока” 2008, nr 9/2. 
obszernej kolekcji tekstów tradycji chan, zgromadzonych przez Zongmiego. Ów kanon tekstów zaginął; do czasów współczesnych zachowała się tylko Przedmowa ${ }^{12}$. Kanon razem z Przedmowa cieszył się znaczną popularnością i przyczynił się do wytworzenia wizji chanu jako spójnego nurtu ${ }^{13}$. Model drogi łączącej studiowanie sutr z medytacją, który propagował Zongmi, to - oparty na Sutrze doskonatego oświecenia (Yuánjué jīng 圓覺經), Wzbudzeniu wiary w mahajanę (Dàshéng qǔxìn lùn 大乘起信論) i Awatansakasutrze (Avatamsaka-sūtra, huáyán jīng 華嚴經) ${ }^{14}$-model „nagłego oświecenia i stopniowej kultywacji” (dùnwù jiānxīü 頓悟漸修). Nagłego (wstępnego) oświecenia doznaje się podczas studiowania sutr lub śastr; stopniowa kultywacja natomiast następuje później i stanowi doskonalenie owego nagłego oświecenia ${ }^{15}$. Sam Zongmi miał osiągnąć oświecenie dwukrotnie - najpierw podczas lektury Sutry doskonałego oświecenia ${ }^{16}$, a następnie czytając komentarz Chengguana (Chéngguàn 澄觀, 738-839) do Awatansakasutry ${ }^{17}$.

Drugą główną postacią w ramach nurtu wenzi chan był Yongming Yanshou (Yǒngmíng Yánshòu 永明延壽, 904-976), który będąc kontynuatorem myśli Zongmiego, przyczynił się w dużej mierze do rozpowszechnienia jego koncepcji w okresie dynastii Song (960-1279). Uczynił to, zamieszczając w swoim głównym dziele, Zongjing lu (Zōngjìng lù 宗鏡錄), fragmenty nauk Zongmiego. Podobieństwo Zongjing lu do dzieła Zongmiego jest wyraźne ${ }^{18}$. Poglądy Yanshou miały duży wpływ w początkach północnej dynastii Song (960-1126), dzięki działalności cieszącego się podówczas autorytetem przedstawiciela szkoły winaji (lüzōng 律宗) ${ }^{19}$, Zanninga (Zànníng 賛寧, 919-1001), który propagował poglądy głoszone przez przedstawicieli szkoły fayan ${ }^{20}$.

Sytuacja uległa zmianie, gdy rząd zaczął wspierać rozwijającą się szkołę linji. W literaturze buddyzmu chan zaczęły dominować gatunki literackie, takie jak „zapiski mów” (yǔlù 語錄) i „,zapiski lampy” (dēnglù 燈錄), które obecnie uznawane są za najbardziej charakterystyczne dla tradycji chan ${ }^{21}$. Ścisły, krytyczny styl traktatów Zongmiego i Yanshou stawał się coraz bardziej nietypowy dla tradycji chan, a dziś jego przynależność do chanu może budzić nawet zdziwienie. Niemniej wenzi chan rozwinął się w XIII wieku w Korei okresu Goryeo (918-1392) dzięki działalności

${ }^{12}$ Zob. J. Broughton, op.cit., s. 22-23.

${ }_{13}$ Ibidem, s. 16; A. Ferguson, Zen's Chinese Heritage, Boston 2000, s. 270.

${ }^{14}$ P. Gregory, Sudden Enlightenment Followed by Gradual Cultivation: Tsung-mi's Analysis of Mind [w:] Sudden and Gradual Approaches to Enlightenment in Chinese Thoughts, P. Gregory (red.), Delhi 1991, s. 286.

${ }^{15}$ Zob. ibidem, s. 279-320.

16 P. Gregory, Tsung-Mi and the Sinification of Buddhism, Honolulu 2002, s. 52-53.

17 Ibidem, s. 58-59.

${ }^{18}$ Zob. A. Welter, op.cit., s. 8.

${ }^{19}$ Szkoła utworzona w VII w., która specjalizowała się w studiowaniu buddyjskiej reguły klasztornej i etyki. Znak 宗 oddaję w tekście jako „szkoła” (dotyczy to również pozostałych omawianych w artykule tradycji), choć warto zaznaczyć, że ma on znacznie szersze pole znaczeniowe (zob. A. Welter, op.cit., s. $45-51,287)$.

${ }^{20}$ A. Welter, The Linji Lu and the Creation of Chan Orthodoxy, New York 2008, s. 36-38.

${ }^{21}$ Ibidem, s. 39-41. 
Jinula (知訥, 1158-1210), który uznawany jest za twórcę dojrzałej tradycji buddyzmu seon $^{22}$ i prekursora największej organizacji buddyjskiej we współczesnej Korei - zakonu Jogye (曹溪). Jinul według przekazów trzykrotnie osiągnął oświecenie, podobnie jak Zongmi, czytając teksty. Były to: Sutra podwyższenia (Tán jīng 壇經), Awatansakasutra i mowy Dahui (Dàhuì Zōnggăo 大慧宗杲, 1089-1163) ${ }^{23}$. Jinul propagował w swoich tekstach również wspomniany model nagłego oświecenia i stopniowej kultywacji zaczerpnięty $\mathrm{z}$ tekstów Zongmiego, stanowiących dla niego, obok tekstów Yanshou, główne źródło inspiracji ${ }^{24}$. Wenzi chan ponadto rozwinął się $\mathrm{w}$ istniejącym w latach 1038-1227 tanguckim królestwie Xixia (Xīxià 西夏), przypuszczalnie funkcjonując w nim w ramach linii przekazu, do której przynależał Zongmi ${ }^{25}$.

Znaczenie nurtu wenzi chan zaczęło się stopniowo zmniejszać w miarę dominacji szkoły linji. Uznanie tradycji linji za przeciwieństwo chanu opartego na literaturze byłoby jednak zbyt dużym uproszczeniem; podobnie jest w przypadku szkoły yunmen. W czasach dynastii Song (960-1279) działali bowiem przedstawiciele obydwu tradycji, którzy bynajmniej nie stronili od studiów nad buddyjską (i nie tylko) literaturą. Jednym z największych erudytów przełomu XI i XII wieku był Huihong (Juéfàn Huihóng 覺範慧洪, 1071-1128), który przynależał do tradycji huanglong linji (huánglóng línji 黃龍臨濟) ${ }^{26}$. Z kolei żyjący w XI wieku Faxiu (Făyún Făxiù 法雲法秀, 1027-1090), inny erudyta, związany był ze szkołą yunmen ${ }^{27}$.

Pomimo dominacji modelu ,specjalnego przekazu poza nauczaniem” ' $\mathrm{i}$ upowszechnienia się re toryki zaczerpniętej z Yunmen guanglu (Yúnmén guănglù 雲門廣錄) i Linji lu (Línji lù 臨濟錄), głoszącej niezależność chanu, a sutry porównującej do „papieru toaletowego" 28 , postulaty nurtu wenzi chan nie przeminęly wraz z dynastią Song. Utrzymały się do czasów obecnych nawet pomimo popularnego współcześnie przekonania, zgodnie z którym chan (zen) nie stanowi tylko nurtu buddyjskiego, ale jest „duchem wszystkich religii i systemów filozoficznych” ${ }^{29} \mathrm{i}$ - zacytujmy ponownie Suzukiego - można go „dołączyć do anarchizmu lub faszyzmu, komunizmu czy demokracji, ateizmu czy idealizmu albo do jakiejś innej formy dogmatyzmu politycznego czy ekonomicznego" 30 .

${ }^{22}$ Buddyzm seon istniał w Korei już wcześniej w formie „dziewięciu górskich szkół seon” (Seonjong gusan 禪宗九山), które wskutek działalności Jinula zostały objęte wspólną strukturą organizacyjną i zharmonizowane ze stanowiskiem szkół „doktrynalnych” (gyo 教); zob. R. Buswell, Tracing Back the Radiance, Honolulu 1991, s. 9-14.

${ }^{23}$ Warto dodać, że Jinul nie miał stałego nauczyciela, od którego mógłby czerpać wiedzę na temat buddyzmu seon; opierał się głównie na samodzielnych studiach nad tekstami (ibidem, s. 21).

${ }^{24}$ Ibidem, s. 48-49.

${ }^{25}$ K. Solonin, Tangut Chan Buddhism and Guifeng Zong-mi, „Chung-Hwa Buddhist Journal” 1998, nr 11, s. 371-376.

${ }^{26}$ A. Ferguson, op.cit., s. 441.

${ }^{27}$ An-yi Pan, Painting Faith, Leiden-Boston 2007, s. 112; M. Schlütter, How Zen Became Zen, Honolulu 2008, s. 59.

${ }^{28}$ B. Watson, The Zen Teachings of Master Lin-Chi, Boston-London 1993, s. 47 (zob. przyp. 3 na s. 13). Samo upowszechnienie się retoryki nie oznacza jednak, że opisy zachowania mnichów ukazane w owych tekstach można uznać za reprezentatywne dla życia klasztornego w okresie Song.

${ }^{29}$ D.T. Suzuki, op.cit., s. 53.

${ }^{30}$ Idem, Zen i kultura japońska, Kraków 2009, s. 38. 
Cechy tradycji wenzi chan wykazuje współczesny buddyzm chan na Tajwanie. Największe tajwańskie organizacje buddyjskie, takie jak Fagu Shan (făgǔshān 法鼓 山 - znana lepiej jako Dharma Drum Mountain) czy Fo Guang Shan (fóguāngshān 佛光山), będąc zakorzenione w tradycji chan ${ }^{31}$, oprócz licznych klasztorów na Tajwanie i w innych krajach, posiadają także uczelnie obejmujące program studiów buddyjskich. Zhongtai (zhōngtái 中台) natomiast - inna wielka organizacja buddyjska, która powstała na Tajwanie - nie tylko przynależąc do nurtu chan, lecz także postulując wierność klasycznej formie owej tradycji, jako jeden z trzech celów stawia sobie studiowanie buddyjskich pism (2 pozostałe to medytacja i etyka) ${ }^{32}$.

Jeśli chodzi o wpływ Jinula na buddyzm koreański, to cieszył się on zmiennym szczęściem (dotyczy to całego buddyzmu koreańskiego) w okresie Joseon (1392-1897), którego władcy wspierali nie buddyzm, a neokonfucjanizm. Klasztor Songgwang sa (松廣寺) założony przez Jinula, przetrwał jednak zarówno trudne dla buddyzmu koreańskiego wieki, jak też kilka pożarów - i funkcjonuje nadal. O Songgwang sa usłyszano na Zachodzie w latach osiemdziesiątych ubiegłego wieku za sprawą opata klasztoru, Kusana (Gusan 九山, 1908-1983), który doprowadził do jego odrodzenia. Nauczanie Kusana, nawiązujące w pewnym stopniu do ideałów głoszonych przez Jinula, zostało przyćmione przez innych wpływowych nauczycieli tamtego okresu, takich jak Seongcheol (性經, 1912-1993), który propagował model „nagłego oświecenia i nagłej praktyki”, wszelki gradualizm uznając za sprzeczny z zasadami buddyzmu chan ${ }^{33}$. Niemniej nauki Jinula są przez współczesnych koreańskich mnichów nadal studiowane. Warto też wspomnieć o istnieniu angielskich przekładów licznych dzieł Jinula, będących rezultatem pionierskiej działalności translatorskiej, niegdyś ucznia Kusana i mnicha w Songgwang sa, a później profesora na Uniwersytecie Kalifornijskim (UCLA), Roberta Buswella.

Nakreśliwszy z konieczności pobieżnie tylko rozwój nurtu wenzi chan, postaram się teraz odpowiedzieć na pytanie, czy Zongmi stworzył coś nowego, czy może raczej odgrywał rolę kontynuatora jednego $\mathrm{z}$ istniejących już nurtów $\mathrm{w}$ ramach wczesnego buddyzmu chan. Skłaniam się ku drugiej z tych możliwości i w dalszej części artykułu postaram się uzasadnić to stanowisko. Jest ono również zgodne ze stanowiskiem samych twórców tradycji wenzi chan. Yanshou twierdził nawet, że każdy mistrz chan w historii tradycji osiągnął oświecenie dzięki sutrom ${ }^{34}$. Nurt wenzi chan w oczach jego przedstawicieli nie miał zatem charakteru reformatorskiego; stanowił raczej kontynuację czegoś, co istniało od początku tradycji buddyzmu chan.

Poniższą analizę kluczowych dla historii chanu postaci przeprowadziłem, interpretując opis życia mistrza chan, nie jako biografię, ale - za Faure - jako paradygmat

${ }^{31}$ Fo Guang Shan funkcjonuje w ramach linii przekazu tradycji linji, niemniej indentyfikuje się ze wszystkimi szkołami buddyzmu chińskiego; Fagu Shan z kolei reprezentuje tradycję caodong i linji. Obie organizacje przynależą do nurtu „buddyzmu humanistycznego” (rénjiān fójiào 人間佛教).

${ }^{32} \mathrm{http} / / /$ www.ctworld.org/english-96/html/a4TRADITION1.htm [dostęp: 22.01.2017].

${ }^{33}$ R. Buswell, The Zen Monastic Experience, Princeton 1992, s. 100.

${ }^{34}$ A. Welter, Yongming Yanshou `s Conception of Chan, New York 2011, s. 77; idem, The Linji Lu..., s. 36. 
ukazujący sposób myślenia o buddyzmie chan właściwy dla autora (lub autorów) i redaktorów danego tekstu ${ }^{35}$.

Czy można powiedzieć coś pewnego na temat stosunku pierwszego patriarchy chan w Chinach, Bodhidharmy, do studiowania sutr? Jedyny spośród przypisywanych Bodhidharmie tekstów, co do którego panuje zgoda w kwestii autorstwa, czyli Erru sixing lun (Èrrù sìxing lún二入四行論) ${ }^{36}$, pomimo swojej niewielkiej objętości zawiera informacje, z których można wnioskować o stosunku Bodhidharmy do studiowania sutr. Przede wszystkim w tekście tym znajdują się nawiązania wprost do dwóch sutr: do Sutry Wimalakirtiego (Vimalakītinirdeśa-sūtra) w formie cytatu i odniesienie do zawartej w Sutrze lotosu (Saddharmapunḍarīka-sūtra) metafory płonącego domu ${ }^{37}$. Dodatkowo warto wspomnieć, że tradycja buddyzmu chan uznaje Bodhidharmę za nauczyciela, który opierał swoje nauki na Lankawatarasutrze (Lankāvatāra-sütra). Kopie tej właśnie sutry Bodhidharma miał przekazać swojemu następcy, Huike (Dàzǔ Huikě 大祖慧可) ${ }^{38}$. Erru sixing lun obfituje również w odniesienia do rozmaitych koncepcji pochodzących z filozofii buddyjskiej. Są to koncepcje, takie jak: natura buddy (w tekście jako „prawdziwa natura” zhēnxìng 真性) ${ }^{39}$, cztery szlachetne prawdy (jako paralelne wobec czterech praktyk sixing 四行), karman (yè 業) $)^{40}$, powstawanie w zależności (jako paralelne wobec drugiej z czterech praktyk: ,akceptacji uwarunkowań” suí yuán 隨緣), pustka (kōng 空), anatman (wúwǒ 無我 $)^{41}$, sześć paramit (liù dù 六度) ${ }^{42}$. Zważywszy na niewielką objętość tekstu, liczba przywołanych koncepcji jest spora. Jeśli chodzi o stosunek do sutr wyrażony wprost, a nie tylko wywnioskowany, w pierwszej części tekstu, w ramach opisu „wejścia poprzez zasadę" (lìrù 理入), mowa jest o oświeceniu opartym na naukach (jiào 教) ${ }^{43}$. Treścią owego oświecenia jest „prawdziwa natura”, wspólna wszystkim ludziom - zarówno oświeconym, jak i pogrążonym w niewiedzy. Adept dowiaduje się o swojej naturze za pośrednictwem nauk. Po opisie „wejścia poprzez zasadę” następuje opis „,wejścia poprzez praktykę”, którą konstytuują cztery formy praktyki stopniowej. Nie sposób nie odnieść wrażenia, że owe dwa wejścia odpowiadają modelowi nagłego oświecenia i stopniowej kultywacji, który opisał Zongmi. Reasumując, stosunek Bodhidharmy do sutr można określić jako przystający pod zasadniczymi względami do tego, jaki prezentowali przedstawiciele nurtu wenzi chan ${ }^{44}$.

${ }^{35}$ Zob. B. Faure, op.cit., s. 126-135.

36 J. McRae, The Northern School and the Formation of Early Ch'an Buddhism, Honolulu 1986, s. 101.

37 Ibidem, s. 104.

${ }^{38}$ Ibidem, s. 27.

39 二入四行論 (X.63.1217.1a21), http://www.cbeta.org/result/normal/X63/1217_001.htm [dostęp: 25.01.2016].

40 二入四行論 (X.63.1217.1b5), ibidem.

41 二入四行論 (X.63.1217.1b8), ibidem.

42 二入四行論 (X.63.1217.1b24), ibidem.

43 二入四行論 (X.63.1217.1a21), ibidem; na oznaczenie „nauk” użyty został ten sam termin, co w przypadku ,specjalnego przekazu poza nauczaniem”.

${ }^{44}$ Do podobnego wniosku, lecz na podstawie innych przesłanek, doszedł Albert Welter (zob. A. Welter, Mahakasyapa's smile [w:] The Koan. Texts and Contexts in Zen Buddhism, S. Heine, D. Wright (red.), 
Postacią równie ważną co Bodhidharma w historii chanu był Szósty Patriarcha, Huineng (Huìnéng 惠能, 638-713), który został ukazany w Sutrze podwyższenia jako niepiśmienny sprzedawca drewna na opał, stanowiący personifikację natury buddy - pierwotnie istniejącej w każdym człowieku wyzwalającej wiedzy, która, będąc doskonałą, nie potrzebuje niczego z zewnątrz. Huineng - pomimo braku odpowiedniej pozycji społecznej, braku wiedzy teoretycznej i znikomego doświadczenia w praktyce buddyjskiej - otrzymuje od piątego patriarchy potwierdzenie oświecenia i przekaz dharmy ${ }^{45}$. Obraz Huinenga, który nie potrzebuje sutr, został utrwalony przez malarza okresu południowej dynastii Song (1127-1279), Liang Kaia (Liángkǎi 梁楷, 1140 1210) w obrazie przedstawiającym Huinenga targającego sutrę. Wizja postaci Huinenga jako negującego wartość studiów nad literaturą buddyjską utrwaliła się w kulturze. Jest ona jednak sprzeczna z treścią Sutry podwyższenia zawierającą opis życia Huinenga i jego nauki. Po pierwsze, Huineng miał dwukrotnie osiągnąć oświecenie w okolicznościach, które bynajmniej nie świadczą o nieprzydatności sutr. Pierwsze oświecenie nastąpiło, gdy usłyszał mnicha recytującego fragment Sutry diamentowej (Vajracchedikāprajñāpāramitā-sūtra); drugie, gdy wysłuchał objaśnienia Hongrena (Hóngrěn 弘忍, 601-674) do tejże sutry ${ }^{46}$. Oświecenie Szóstego Patriarchy przypomina bardziej to, którego doświadczyli Zongmi i Jinul; nie ma nic wspólnego z nietypowymi, pozawerbalnymi technikami towarzyszącymi okolicznościom oświecenia Yunmena czy Linji ${ }^{47}$. Ponadto w Sutrze pojawiają się nawiązania do innych tekstów, takich jak Sutra nirwany (Mahāparinirvāna-sūtra), Lankawatarasutra, Sutra Wimalakirtiego, Sutra lotosu. Tekst obfituje również w rozmaite koncepcje zaczerpnięte z buddyjskich sutr i śastr, na których omówienie nie pozwalają przyjęte ramy. Co najważniejsze, Sutra podwyższenia zawiera także wypowiedź, w której Szósty Patriarcha wprost krytykuje postawę odrzucającą sutry jako generującą niezliczone przeszkody (na drodze do przebudzenia) ${ }^{48}$. W świetle owej krytyki treść obrazu Liang Kaia wydaje się odbiegać od faktów. Powyższej wypowiedzi Huinenga towarzyszy ogólna krytyka odrzucania tekstów. Huineng stwierdza, że jeśli ktoś odrzuca słowo pisane, to w konsekwencji powinien także przestać mówić. Ów fragment pojawia się zarówno w najstarszej zachowanej wersji Sutry, czyli w edycji z Dunhuang ${ }^{49}$, jak i w późnej edycji z okresu dynastii Yuan ${ }^{50}$. Reprezentuje on zatem stanowisko chanu w okresie rozwoju treści Sutry od IX do XIII wieku ${ }^{51}$.

New York 2000, s. 93-94); interesującej analizy traktatu dokonał też Broughton, zestawiając go z sutrą Śrīmālādevīsiṃhanāda (zob. J. Broughton, The Bodhidharma Anthology, Berkeley-Los Angeles-London 1999, s. 68-74).

45 J. McRae (tłum.), The Platform Sutra of the Sixth Patriarch, Berkeley 2000, s. 17.

46 Ibidem, s. 23.

${ }^{47}$ Oświeceniu pierwszego z nich towarzyszyło zmiażdżenie stopy zamykanymi drzwiami (A. Ferguson, op.cit., s. 283-284). Okoliczności oświecenia Linji natomiast wypełniają opisy uderzeń wymienianych między Linji a jego nauczycielami (Ibidem, s. 173-175).

48 J. McRae (tlum.), op.cit., s. 83; por. T. Cleary (thum.), The Sutra of Hui-neng, Grand Master of Zen, Boston 1998, s. 72.

${ }^{49} \mathrm{Ph}$. Yampolsky (thum.), The Platform Sutra of the Sixth Patriarch, London-New York 1978, s. 173.

${ }_{50}$ T. Cleary (tłum.), op.cit., s. 72; por. J. McRae (tłum.), op.cit., s. 83.

${ }^{51}$ M. Schlütter, Transmission and Enlightenment in Chan Buddhism Seen Through the Platform Sütra (Liuzu tanjing 六祖壇經), „Chung-Hwa Buddhist Journal” 2007, nr 20, s. 385. 
Warto jeszcze wspomnieć, że wczesne edycje Sutry wspominają o rytuale przekazywania, obok szaty, także kopii Sutry podwyższenia, w ramach formalnego przekazu dharmy ${ }^{52}$. Sytuacja jest analogiczna do przekazania kopii Lankawatarasutry przez Bodhidharmę swojemu następcy - Huike. Zatem przekaz, który ostatecznie zaczął być interpretowany jako niezależny od sutr i przeciwstawiany sutrom, początkowo, jak na ironię, był w jednym aspekcie dosłownie przekazem sutr. Mistrzowie przekazywali sobie kopie tekstów. W późniejszym okresie również przekazywano teksty, tyle że nie sutry, ale „przekazy lampy” (chuándēng 傳燈) z wypisaną sukcesją patriarchów danej linii przekazu. Ten zwyczaj trwa do dziś. Podsumowując, należy stwierdzić, że autor (lub autorzy) Sutry podwyższenia był dobrze zaznajomiony z buddyjską doktryną i wysoko cenił sutry.

Innym wpływowym mistrzem chan, który kojarzony jest z ikonoklazmem, był Mazu (Măzŭ Dàoȳ̄ 馬祖道一, 709-788). Jest on uznawany za prekursora specyficznych dla tradycji chan metod doprowadzania adeptów do przebudzenia. Są to takie metody, jak okrzyki, uderzenia czy dziwne zaskakujące zwroty ${ }^{53}$. Owe techniki postrzegane są jako służące zatrzymywaniu konceptualizacji, codziennego myślenia opartego na dychotomiach, tak aby czysty umysł mógł się zamanifestować. Są uznawane za przeciwieństwo studiów nad doktryną. Niemniej jednak teksty przypisywane Mazu zawierają odniesienia do licznych sutr i śastr, których liczba, zważywszy na niewielką objętość zbioru tekstów Mazu, jest imponująca nie tylko w odniesieniu do standardów buddyzmu chan. Mazu odwołuje się między innymi do następujących tekstów: Awatansakasutra, Lankawatarasutra, Sutra nirwany, Sutra lotosu, Śrīmālādevīsiṃhanāda-sūtra, Sukhāvatīvyūha-sūtra, Vajrasamādhi-sūtra, Buddhanama-sūtra, Wzbudzenie wiary w mahajanę, Ratnagotravibhāga ${ }^{54}$. Mazu musiał więc sporo czytać i najwyraźniej jego wiedza na temat buddyjskiej doktryny była zaawansowana. Interesujące jest również to, że Mazu w jednej ze swoich mów ukazuje Bodhidharmę jako tego, który używał Lankawatarasutry, aby uwiarygodniać swoje nauczanie. Sutra owa, zdaniem Mazu, stanowiła dla Bodhidharmy punkt odniesienia $\mathrm{w}$ jego nauczaniu ${ }^{55}$. W taki sam sposób postrzegali sutry przedstawiciele nurtu wenzi chan.

W świetle powyższych rozważań stwierdzić można, że rozpowszechnione przekonanie o tym, iż tradycja chan stanowi przekaz niezależny od sutr, nie znajduje potwierdzenia w przypadku wczesnego buddyzmu chan, a także w przypadku wielu powstałych później szkół. Pomimo wniosków wypływających z trzech przedstawionych powyżej analiz, z których jednoznacznie wynika, że stosunek Bodhidharmy, Huinenga i Mazu do sutr określić można jako pozytywny, w tekstach owych mistrzów chan nie brakuje jednak krytyki nadmiernego przywiązania do studiów teoretycznych. Przykładowo, Bodhidharma wspomina o niepodążaniu (bù suí 不隨) za

52 Ibidem, passim.

${ }_{53}$ M. Poceski, Ordinary Mind as the Way, New York 2007, s. 9, 237.

${ }^{54}$ Jia Jinhua, The Hongzhou School of Chan Buddhism, Albany 2006; szczegółowy wykaz tekstów cytowanych przez Mazu i innych przedstawicieli szkoły hongzhou (hóngzhōu 洪州) podaje Poceski (M. Poceski, op.cit., s. 145).

${ }^{55}$ Ibidem, s. 119-120. 
spisanymi naukami (wénjiào文教) ${ }^{56}$. Sutra podwyższenia z kolei zawiera fragmenty, w których pojawia się krytyka teoretyzowania, jakiemu nie towarzyszy bezpośrednie doświadczenie wglądu. Zostaje to porównane do mówienia o jedzeniu zamiast zaspokojenia głodu ${ }^{57}$. Podkreślanie praktycznego aspektu buddyjskiej ścieżki jest jednak zjawiskiem występującym w tradycji buddyjskiej od samego początku. Już w suttach kanonu palijskiego odnajdujemy liczne fragmenty podkreślające pragmatyzm buddyjskiej ścieżki. Stanowisko buddyzmu chan jest jedynie kwestią stopnia - chan w większym stopniu, niż inne szkoły buddyzmu chińskiego, kładzie akcent na osiąganie osobistego doświadczenia. Jeśli potraktujemy chan jako nurt wyłącznie skupiony na bezpośrednim doświadczeniu i negujący wartość znajomości sutr i śatr ukazujących buddyjską doktrynę, pojawi się pytanie o przynależność tradycji chan do religii buddyjskiej. Łączy się to znacząco z przekonaniem wyrażanym przez współczesnych nauczycieli zen, zgodnie z którym chan/zen jest zjawiskiem uniwersalnym, wykraczającym poza buddyzm ${ }^{58}$. Takie ujęcie owej tradycji stanowi jednak odrębne zjawisko, które wymaga osobnej analizy.

\section{Bibliografia}

Abe M., Zen and Comparative Studies, London 1997.

Benická J., Chan Buddhism and Huayan: Yongjue Yuanxian (1578-1657) on the „Five Positions” (wu wei) Theory of Dongshan Liangjie, „Письменные памятники Востока” 2008, nr 9/2.

Broughton J., The Bodhidharma Anthology, Berkeley-Los Angeles-London 1999.

Broughton J., Zongmi on Chan, New York 2009.

Buswell R., Tracing Back the Radiance, Honolulu 1991.

Buswell R., The Zen Monastic Experience, Princeton 1992.

Cleary T. (tlum.), The Sutra of Hui-neng, Grand Master of Zen, Boston 1998.

二入四行論 (X.63.1217), http://www.cbeta.org/result/normal/X63/1217_001.htm [dostęp: 25.01. 2016].

Faure B., Chan Insights and Oversights, Princeton 1993.

Ferguson A., Zen's Chinese Heritage, Boston 2000.

Gregory P., The Place of the Sudden Teaching within the Hua-yen Tradition: An Investigation of the

Process of Doctrinal Change, „Journal of the International Association of Buddhist Studies” $1983, \mathrm{nr} 6 / 1$.

Gregory P., Sudden Enlightenment Followed by Gradual Cultivation: Tsung-mi's Analysis of Mind

[w:] Sudden and Gradual Approaches to Enlightenment in Chinese Thoughts, P. Gregory (red.),

Delhi 1991.

56 J. Broughton, op.cit., s. 9; por. J. McRae, The Northern School..., s. 103; 二入四行論 (X.63. 1217.1a23), http://www.cbeta.org/result/normal/X63/1217_001.htm [dostęp: 30.01.2016].

57 J. McRae (ttum.), The Platform Sutra.., s. 28.

${ }^{58}$ Do przywołanej już wypowiedzi Suzukiego można jeszcze dołączyć zdanie z wpływowej książki Shibayamy: „można [...] rozumieć zen w szerokim znaczeniu jako zen sam w sobie, w odróżnieniu od wąskiej, sekciarskiej interpretacji określającej zen jako szkołę buddyzmu. W szerokim znaczeniu zen nie ogranicza się do samego buddyzmu, ale oznacza Prawdę czy też Absolut i jest podstawą wszystkich religii i filozofii; nie jest po prostu rdzeniem buddyzmu, lecz pracuje dla pogłębienia każdej religii czy filozofii. Może na przykład istnieć zen chrześcijański czy zen taoistyczny...” (Z. Shibayama, Milczenie kwiatu. Eseje zen, tłum. B. i D. Stobieccy, Kraków 1998, s. 14). 
Gregory P., Tsung-Mi and the Sinification of Buddhism, Honolulu 2002.

Hisamatsu S., Critical Sermons of the Zen Tradition, tłum. Ch. Ives, G. Tokiwa, New York 2002.

Jia Jinhua, The Hongzhou School of Chan Buddhism, Albany 2006.

McRae J., The Northern School and the Formation of Early Ch an Buddhism, Honolulu 1986.

McRae J. (thum.), The Platform Sutra of the Sixth Patriarch, Berkeley 2000.

Nishitani K., The philosophy of Nishitani Keiji 1900-1990: Lectures on Religion and Modernity, tłum. J. Augustine, S. Yamamoto, New York 2012.

Pan An-yi, Painting Faith, Leiden-Boston 2007.

Poceski M., Ordinary Mind as the Way, New York 2007.

Schlütter M., How Zen Became Zen, Honolulu 2008.

Schlütter M., Transmission and Enlightenment in Chan Buddhism Seen Through the Platform Sūtra (Liuzu tanjing 六祖壇經), „Chung-Hwa Buddhist Journal” 2007, nr 20.

Shibayama Z., Milczenie kwiatu. Eseje zen, tłum. B. i D. Stobieccy, Kraków 1998.

Solonin K., Tangut Chan Buddhism and Guifeng Zong-mi, „Chung-Hwa Buddhist Journal” 1998, nr 11.

Suzuki D.T., Wprowadzenie do buddyzmu zen, Kraków 2009.

Suzuki D.T., Zen i kultura japońska, Kraków 2009.

Watson B. (thum.), The Zen Teachings of Master Lin-Chi, Boston-London 1993.

Welter A., The Linji Lu and the Creation of Chan Orthodoxy, New York 2008.

Welter A., Mahakasyapa's smile [w:] The Koan. Texts and Contexts in Zen Buddhism, S. Heine, D. Wright (red.), New York 2000.

Welter A., Yongming Yanshou's Conception of Chan, New York 2011.

Yampolsky Ph. (thum.), The Platform Sutra of the Sixth Patriarch, London-New York 1978.

http://www.ctworld.org/english-96/html/a4TRADITION1.htm [dostęp: 22.01.2017]. 